\title{
A MODEL FOR TURNOVER INTENTION: BANKING INDUSTRY IN MALAYSIA
}

\author{
Mohammad Falahat*, Gee Siew Kit, and Liew Chin Min \\ Faculty of Accountancy and Management, Universiti Tunku Abdul Rahman, \\ 43000 Kajang, Selangor, Malaysia \\ *Corresponding author email: falahat@utar.edu.my
}

Published online: 25 October 2019

To cite this article: Falahat, M., Gee, S.K., and Liew, C.M. (2019). A model for turnover intention: Banking industry in Malaysia. Asian Academy of Management Journal, 24(Supp. 2), 79-91. https://doi.org/10.21315/aamj2019.24.s2.6

To link to this article: https://doi.org/10.21315/aamj2019.24.s2.6

\begin{abstract}
The issue of staff's intention to leave is a huge concern for senior management and human resource managers. It is one of the costliest and most challenging issues within any organisation worldwide. The banking industry records the highest turnover rate in Malaysia. High employee turnover has a profound influence on the banks' performance and productivity. The primary purpose of this research is to explore the real causes of turnover intention in the banking industry in Malaysia. The result from a total of 395 respondents showed that working environment, job enrichment, and job stress could significantly affect job satisfaction; whereas job stress and job satisfaction will substantially affect turnover intention. The results also found that working environment and job stress have an indirect effect on turnover intention.
\end{abstract}

Keywords: turnover intention, job enrichment, job stress, job satisfaction, banking industry

\section{INTRODUCTION}

In recent years, turnover has become a culture or trend in almost all industries. High turnover has become a crucial and problematic issue that concerns all companies as it will affect the company's overall profitability (Mohammad et al., 2014). Previous studies on turnover found that many organisations face challenges in hiring and retaining talent in their organisation because of increasing demand and better opportunities that lead employees to decide relocating to another

(C) Asian Academy of Management and Penerbit Universiti Sains Malaysia, 2019. This work is licensed under the terms of the Creative Commons Attribution (CC BY) (http://creativecommons. org/licenses/by/4.0/). 
organisation (Awang, Amir \& Osman, 2013). The rise of voluntary turnover from year to year puts the company into a challenging situation in maintaining the workforce and coordinating activities in the company. The problem of insufficient workforce will limit the growth of a business and burden the existing staff with extra responsibilities which will lead to job stress (Harper, 2016). Statistics show that Malaysia's financial services industry has a greatly increasing turnover rate from $7.4 \%$ in 2012 to $13.3 \%$ in 2013 (Willis Towers Watson, 2013). The financial and banking sector is found to have the highest turnover rate with $18.3 \%$ (Letchumanan, Apadore \& Ramasamy, 2017). High turnover is an unfavourable situation that will result in increased costs in terms of recruitment, training, and development as well as benefits and compensation. When an employee leaves the organisation, the management has to incur additional expenses by recruiting new staff, designing a new salary package, and providing training course (Javed, Balouch \& Hassan, 2014). Eventually, it will have a negative impact on the bank's performance in the market in terms of profit margin. Despite increased salary (Willis Towers Watson, 2013), the turnover rate of employees in the banking industry in Malaysia remains high. This implies a need to understand the key determinants of employee turnover intention as the main contributor to the high turnover rate in Malaysia. In this study, we examine the factors that affect employee turnover intention in the banking industry. The findings will help human resources managers to better align their employee retention programme instead of focusing only on salary increment, thus improving the bank's productivity and overall performance.

\section{LITERATURE REVIEW}

\section{Turnover Intention}

Turnover is the moving of employment from one company to another company by an employee, and this is a crucial issue for many companies. The turnover will severely impact the company's performance, reduce productivity, lower service quality, and increase costs such as recruitment cost (Letchumanan, Apadore \& Ramasamy, 2017).

Turnover intention is a good and reliable indicator to predict the actual turnover (Liu \& Onwuegbuzie, 2012). Bhatnagar (2012) stated that turnover intention is a key to modelling the employee turnover intention and the turnover intention is related to the actual turnover. Turnover intention can also be referred to as a turnover plan or turnover tendency. It is a behavioural tendency that prompts the employee to seek to leave the company and this may lead to the actual turnover (Mohammad et al., 2014). 


\section{Working Environment}

Jain and Kaur (2014) stated that the working environment or working condition consists of three main elements which are the physical, mental, and social environments. Raziq and Maulabakhsh (2015) established a model for their study on the working environment and job satisfaction. The working environment under their model consists of working hours, job safety and security, relationship with a peer, esteem needs, and top management of the organisation. Poor and unfavourable working condition is one of the primary reasons for the high degree of turnover intention (Qureshi et al., 2013). The quality of supervision will also influence the turnover intention. Poor guidance and support from the manager will lead to a high-degree stress and may even influence the turnover intention.

It is said that the working environment has a positive association with job satisfaction, where the better the working environment, the more it will increase job satisfaction. Raziq and Maulabakhsh (2015), and Johnson, Kraft and Papay (2012) investigated the relationship of the working environment on the job satisfaction and proved that a sound working environment has a positive relationship with job satisfaction while Idson (1990) found that a rigid type of working environment will reduce job satisfaction while a flexible environment tends to have higher job satisfaction. From here, we can conclude that the working environment has a significant positive relationship towards job satisfaction. Therefore, we propose the following hypothesis:

H1: Working environment has a positive effect on job satisfaction

Dane and Brummel (2014) argued that a good working environment tends to reduce the turnover intention of the employee. AlBattat and Som (2013) conducted a study on the relationship between the working environment and turnover intention. They studied the hospitality industry and tourism employment in Malaysia. They concluded that the working environment has a negative relationship toward the turnover intention. Zhang et al. (2014) studied the relationship between working environment and turnover in the hospitality industry in China. Their results showed that the working environment has a negative association with turnover intention. Based on the above argument, we propose that working environment has negative relationship with turnover intention.

H2: Working environment has a negative effect on turnover intention 


\section{Salary}

Chaudhry et al. (2011) mentioned that salary is a kind of compensation for an employee by the company. Salary is one of the main costings for the company's running operation. There is a different salary range for different positions. A company can use salary as a reward to motivate or shape the behaviour of an employee. Even though there are other factors that influence job satisfaction, salary is one of the main determinants for an employee's job satisfaction. Empirical research has proven that if the company fails to pay an adequate salary, it will cause dissatisfaction on the employee's part, and may even be a catalyst for the turnover (Lee \& Sabharwal, 2016).

Kumar (2016) researched the public banking sector in India and found that salary has a positive relationship with job satisfaction. Lee and Sabharwal (2016) have done a research to study salary and job satisfaction among the United States college graduates and found that higher salary will lead to higher job satisfaction.

\section{H3: Salary has a positive effect on job satisfaction}

Research works conducted on salary and turnover intention found that salary has negative relationship with turnover intention (Kim \& Stoner, 2008; Luna-Arocas \& Camps, 2007). However, Lee, Huang and Zhao (2012) conducted a study in the hotel industry in Taiwan, and the result showed that salary didn't have a significant relationship with turnover intention. Guan et al. (2014) investigated how salary affects turnover intention in China. Their study showed that salary has negative relationship with turnover intention. Based on the above, we can conclude and form a hypothesis statement that salary has negative relationship toward turnover intention.

H4: Salary has a negative effect on turnover intention

\section{Job Enrichment}

Job enrichment is a concept where employees of an organisation gain greater satisfaction in their work through more challenging tasks which may help the employees attain a higher sense of worth (Feder, 1999). Mosadeghrad and Ferdosi (2013) stated that job enrichment could be as one of the motivation strategies other than job rotation to increase employee satisfaction. Job enrichment provides the employees opportunities to achieve their potential through on job challenges and gain recognition. Through this job enrichment, the commitment of employee will increase. Salleh, Nair and Harun (2012) opine that job enrichment would be 
useful in administrative operations as job enrichment will increase the freedom, independence, responsibility, and authority of the employee, which in turn will contribute to higher job satisfaction and lower job stress.

Cook and Salvendy conducted research (1999) and found out that job enrichment has a positive relationship with job satisfaction. Tausif (2012) and Kooij et al. (2013) also found that job enrichment will positively affect job satisfaction. Therefore, we propose the hypothesis below:

H5: Job enrichment has a positive effect on job satisfaction

Heilmann, Holt and Rilovick (2008), and Lam, Lo and Chan (2002) conducted their studies on the factors that affect turnover intention. They found that job enrichment can be used as a method to reduce turnover intention. Baba and Jamal (1991) investigated how job enrichment affects turnover intention. They conducted a study based on Canadian nurses and their results showed that job enrichment lowered the impact of turnover intention and also improved the quality of working life. Based on the above, we propose the following hypothesis:

H6: Job enrichment has a negative effect on turnover intention

\section{Job Stress}

Mosadeghrad (2013) noted that the unmatching between the demand of work and employee's ability to cope will cause the job stress. Finney et al. (2013) said that long term job stress would cause adverse syndrome responses such as burnout, emotional exhaustion, and other negative feelings. Job stress and burnout will not only lead to decreased productivity but will also affect staff's commitment to the organisation.

Nowadays, job stress is a problem in modern life, and a common issue shared by many companies. It affects not only the individual but also the company's standing or performance, such as the company's outcome and turnover rate. An employee under stress becomes demotivated, develops a poor health condition, and becomes less productive (Arshadi \& Damiri, 2013). This may directly impact the company's performance and success.

Mosadeghrad (2013), and Arshadi and Damiri (2013) have found that job stress has a negative relationship with job satisfaction. Research has also been conducted by Reilly, Dhingra and Boduszek (2014) to investigate how job stress affects job 
satisfaction and they found that job stress will negatively influence job satisfaction. Based on the above, we propose the following hypothesis:

H7: Job stress has a negative effect on job satisfaction

Jung and Yoon (2014) studied the food service industry to understand how job stress affects turnover intention. A similar study has also been conducted by Arshadi and Damiri (2013), and Jou, Kuo and Tang (2013) to find out the relationship between job stress and turnover intention. The results showed that job stress has a positive relationship toward turnover intention. Based on the above, we propose the following hypothesis:

H8: Job stress has a positive effect on turnover intention

\section{Job Satisfaction}

Locke (1976) defined job satisfaction as an emotional state of a person on his or her work or working experiences (Fu \& Deshpande, 2014). While Belias and Koustelios (2014) stated that job satisfaction is a multidimensional factor that is influenced by different external factors and internal factors, and used Herzberg Two-factor Theory to explain that job satisfaction can be influenced by motivator factors (satisfiers) and hygiene factors (dissatisfiers).

According to Gabrani et al. (2016), job satisfaction is an individual's feelings toward their jobs or the general attitude of the employee towards the job. There are three focus dimensions for job satisfaction which are: (1) job situation's emotional response; (2) the expectations for the outcome being met or exceeded; and (3) work content, compensation, career advancement, colleagues, and supervision.

Olusegun (2013), Scanlan and Still (2013), and Kuo, Lin and Li (2014) investigated the effect of job satisfaction on turnover intention. All the findings' outcome showed that job satisfaction has a negative relationship on turnover intention. Based on the above, we propose the following hypothesis:

H9: Job satisfaction has a significant negative relationship with turnover intention

Besides that, we also propose that job satisfaction will have the mediation effect between working environment, salary, job enrichment and job stress, and turnover intention. Therefore, we propose that job satisfaction will have the mediation effect between working environment and turnover intention. 
H10: Job satisfaction mediates the effect between the working environment and turnover intention

H11: Job satisfaction mediates the effect of salary and turnover intention

H12: Job satisfaction mediates the effect of job enrichment and turnover intention

H13: Job satisfaction mediates the effect between job stress and turnover intention

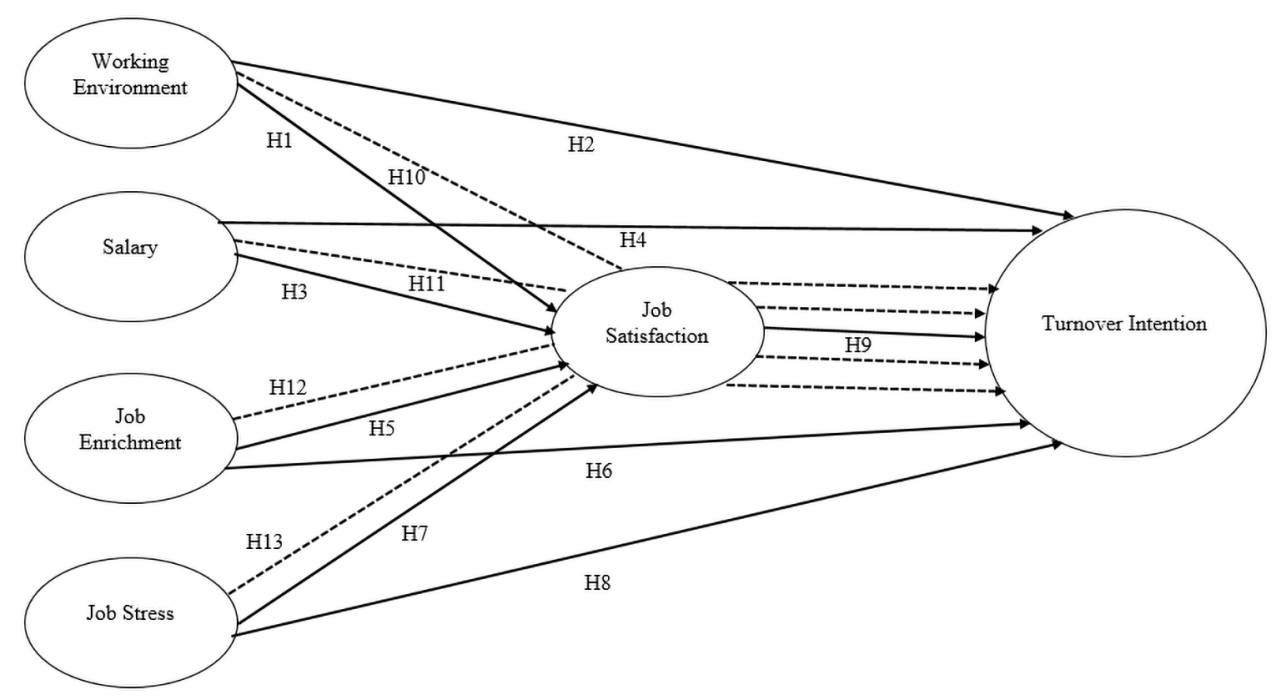

Figure 1. Research framework

\section{RESEARCH METHODOLOGY}

In this research, the banking industry was chosen as the target population. Convenience non-probability sampling method was used to collect the data. A total of 421 out of 500 questionnaires were received. A number of 395 questionnaires were used as 21 respondents were not qualified, and five respondents were biased in answering the questions. The data analysis will mainly use SmartPLS to run the construct reliability and bootstrapping analysis. 


\section{RESULTS AND DISCUSSION}

This model consists of two $R^{2} S$, which are $R^{2}$ of job satisfaction and turnover intention. For job satisfaction, the value of $\mathrm{R}^{2}$ is 0.577 , while $\mathrm{R}^{2}$ value for turnover intention is 0.407 . This means $57.7 \%$ of job satisfaction can be explained by working environment, salary, job stress, and job enrichment; and $40.7 \%$ of turnover intention can be explained by working environment, salary, job stress, job enrichment, and job satisfaction.

According to Zikmund et al. (2009), the value of Cronbach's alpha should be at least or larger than $0.700(\geq 0.700)$. From Table 1 , all the constructs used are above 0.700 which from 0.806 to 0.913 . Based on the rule of Cronbach's alpha analysis, all of the constructs are considered reliable.

A composite reliability (CR) value ofmore than $0.700(\geq 0.700)$ is acceptable and considered as satisfactory and the values below 0.600 considered as lack of internal consistency reliability. According to the results, CR values of each construct are more than $0.700(\geq 0.700)$ which is 0.860 to 0.929 . We can conclude that all of the constructs have satisfactory internal consistency reliability.

An average variance extracted (AVE) value with at least or more than 0.500 $(\geq 0.500)$ represents that the constructs averagely explain more than half of the variance of its indicators, which is considered satisfactory. Based on the results, all of our constructs' AVE have more than $0.500(\geq 0.500)$ which is 0.508 to 0.753 . From the results, all of the constructs are satisfactory and averagely explain more than half of the variance.

Table 1

Construct reliability

\begin{tabular}{lcccc}
\hline Construct & Cronbach's alpha & CR & AVE & R $^{2}$ \\
\hline Turnover intention & 0.891 & 0.924 & 0.753 & 0.407 \\
Working environment & 0.865 & 0.900 & 0.601 & \\
Salary & 0.806 & 0.860 & 0.508 & \\
Job enrichment & 0.881 & 0.918 & 0.737 & \\
Job stress & 0.913 & 0.929 & 0.620 & \\
Job satisfaction & 0.878 & 0.911 & 0.672 & 0.577 \\
\hline
\end{tabular}


Table 2

Hypothesis results for research model

\begin{tabular}{llcc}
\hline Hypothesis & Std beta & $p$-value & Decision \\
\hline H1: Working environment -> Job satisfaction & 0.571 & 0.000 & Supported \\
H2: Working environment -> Turnover intention & -0.094 & 0.219 & Not supported \\
H3: Salary -> Job satisfaction & 0.039 & 0.394 & Not supported \\
H4: Salary -> Turnover intention & -0.050 & 0.339 & Not supported \\
H5: Job enrichment -> Job satisfaction & 0.132 & 0.009 & Supported \\
H6: Job enrichment -> Turnover intention & -0.099 & 0.071 & Not supported \\
H7: Job stress -> Job satisfaction & -0.145 & 0.002 & Supported \\
H8: Job stress -> Turnover intention & 0.345 & 0.000 & Supported \\
H9: Job satisfaction -> Turnover intention & -0.214 & 0.005 & Supported \\
H10: Working environment -> Job satisfaction & -0.122 & 0.007 & Supported \\
$\quad$ Job satisfaction -> Turnover intention & & & \\
H11: Salary -> Job satisfaction -> Turnover intention & -0.008 & 0.454 & Not supported \\
H12: Job enrichment -> Job satisfaction -> Turnover & -0.028 & 0.088 & Not supported \\
$\quad$ intention & & & \\
H13: Job stress -> Job satisfaction -> Turnover & 0.031 & 0.040 & Supported \\
$\quad$ intention & & & \\
\hline
\end{tabular}

From the bootstrapping analysis, the results show that working environment, job enrichment, and job stress are significant to job satisfaction (H1, H5, H7); while only job stress and job satisfaction are significant to turnover intention (H8, H9); and job satisfaction have full mediation effect on the working environment and turnover intention, and partial mediation effect on job stress and turnover intention (H10, H13). Working environment and salary are not significant to job satisfaction $(\mathrm{H} 2, \mathrm{H} 3)$; salary and job enrichment are not significant to turnover intention $(\mathrm{H} 4$, H6); and job satisfaction did not have the mediation effect between salary and job enrichment and turnover intention (H11, H12).

The study has theoretical and practical contributions. It contributes to the understanding of the factors that affect turnover intention in the banking industry in Malaysia. Particularly, we examine job satisfaction as a mediator between working environment, salary, job enrichment, job stress, and turnover intention. Future research on employee turnover intention may extend this model by linking other factors to job satisfaction as a mediator. For human resource managers from the banking industry, our findings suggest that salary is not an influential factor for employee retention. Managers who wish to maintain quality staff should enhance their job satisfaction through attention on the working environment, job enrichment, and job stress management. Banking corporations should monitor 
closely the factors that are found to have an effect on employees' job satisfaction. An annual employee's satisfaction survey on the critical factors highlighted in this study can benefit both employers and employees for long-term employment. Nevertheless, the study also has a limitation. The focus on banking industry limits the generalisability of this model to other sectors. Future study may consider testing this model across different industries.

\section{CONCLUSION}

Overall, this study reveals the roles of working environment, salary, job enrichment, job stress, and job satisfaction on employee turnover intention in the banking industry. Based on the results, job satisfaction and job stress play an important role in the turnover intention of banking employees. To enhance job satisfaction, the bank should enhance the working environment, job enrichment and reduce job stress. Working environment will enhance job satisfaction and indirectly reduce the turnover intention. Job stress is one of the critical issues for a bank to handle as it will directly affect the employee's turnover intention where higher the job stress, the higher the turnover intention will be.

\section{REFERENCES}

AlBattat, A.R.S., \& Som, A.P.M. (2013). Employee dissatisfaction and turnover crises in the Malaysian hospitality industry. International Journal of Business and Management, 8(5), 62. https://doi.org/10.5539/ijbm.v8n5p62

Arshadi, N., \& Damiri, H. (2013). The relationship of job stress with turnover intention and job performance: Moderating role of OBSE. Procedia-Social and Behavioral Sciences, 84, 706-710. https://doi.org/10.1016/j.sbspro.2013.06.631

Awang, A., Amir, A.R., \& Osman, W. (2013). Job behavioral factors and turnover intention: A case study at Sime Darby Property Limited. International Journal of Advances in Management and Economics, 2(6), 103-115.

Baba, V.V., \& Jamal, M. (1991). Routinization of job context and job content as related to employees' quality of working life: A study of Canadian nurses. Journal of Organizational Behavior, 12(5), 379-386.

Belias, D., \& Koustelios, A. (2014). Organizational culture and job satisfaction: A review. International Review of Management and Marketing, 4(2), 132.

Bhatnagar, J. (2012). Management of innovation: Role of psychological empowerment, work engagement and turnover intention in the Indian context. The International Journal of Human Resource Management, 23(5), 928-951. https://doi.org/10.10 $80 / 09585192.2012 .651313$ 
Chaudhry, M.S., Sabir, H.M., Rafi, N., \& Kalyar, M.N. (2011). Exploring the relationship between salary satisfaction and job satisfaction: A comparison of public and private sector organizations. The Journal of Commerce, 3(4), 1-14.

Cook, J.R., \& Salvendy, G. (1999). Job enrichment and mental workload in computer-based work: Implications for adaptive job design. International Journal of Industrial Ergonomics, 24(1), 13-23. https://doi.org/10.1016/S0169-8141(98)00084-5

Dane, E., \& Brummel, B.J. (2014). Examining workplace mindfulness and its relations to job performance and turnover intention. Human Relations, 67(1), 105-128. https://doi.org/10.1177/0018726713487753

Feder, I. (1999). Customized job enrichment and its effect on job performance. Unpublished dissertation, City University of New York.

Finney, C., Stergiopoulos, E., Hensel, J., Bonato, S., \& Dewa, C.S. (2013). Organizational stressors associated with job stress and burnout in correctional officers: A systematic review. BMC Public Health, 13(1), 82. https://doi.org/10.1186/14712458-13-82

Fu, W., \& Deshpande, S.P. (2014). The impact of caring climate, job satisfaction, and organizational commitment on job performance of employees in a China's insurance company. Journal of Business Ethics, 124(2), 339-349. https://doi. org/10.1007/s10551-013-1876-y

Gabrani, A., Hoxha, A., Gabrani, J., Petrela, E., Zaimi, E., \& Avdullari, E. (2016). Perceived organizational commitment and job satisfaction among nurses in Albanian public hospitals: A cross-sectional study. International Journal of Healthcare Management, 9(2), 110-118. https://doi.org/10.1179/2047971915Y.0000000019

Guan, Y., Wen, Y., Chen, S. X., Liu, H., Si, W., Liu, Y., Wang, Y., Fu, R., Zhang, Y., \& Dong, Z. (2014). When do salary and job level predict career satisfaction and turnover intention among Chinese managers? The role of perceived organizational career management and career anchor. European Journal of Work and Organizational Psychology, 23(4), 596-607.

Harper, M.N. (2016). Understaffing issues in the workplace. Chron.com, 26 October. Retrieved 15 February 2017 from http://smallbusiness.chron.com/understaffingissues-workplace-46884.html.

Heilmann, S.G., Holt, D.T., \& Rilovick, C.Y. (2008). Effects of career plateauing on turnover: A test of a model. Journal of Leadership \& Organizational Studies, 15(1), 59-68. https://doi.org/10.1177/1548051808317999

Idson, T.L. (1990). Establishment size, job satisfaction and the structure of work. Applied Economics, 22(8), 1007-1018. https://doi.org/10.1080/00036849000000130

Jain, R., \& Kaur, S. (2014). Impact of work environment on job satisfaction. International Journal of Scientific and Research Publications, 4(1), 1-8.

Javed, M., Balouch, R., \& Hassan, F. (2014). Determinants of job satisfaction and its impact on employee performance and turnover intentions. International Journal of Learning and Development, 4(2), 120-140. https://doi.org/10.5296/ijld. v4i2.6094

Johnson, S.M., Kraft, M.A., \& Papay, J.P. (2012). How context matters in high-need schools: The effects of teachers' working conditions on their professional satisfaction and their students' achievement. Teachers College Record, 114(10), 1-39. 
Jou, R.C., Kuo, C.W., \& Tang, M.L. (2013). A study of job stress and turnover tendency among air traffic controllers: The mediating effects of job satisfaction. Transportation Research Part E: Logistics and Transportation Review, 57, 95104. https://doi.org/10.1016/j.tre.2013.01.009

Jung, H.S., \& Yoon, H.H. (2014). Antecedents and consequences of employees' job stress in a foodservice industry: Focused on emotional labor and turnover intent. International Journal of Hospitality Management, 38, 84-88. https://doi. org/10.1016/j.ijhm.2014.01.007

Kim, H., \& Stoner, M. (2008). Burnout and turnover intention among social workers: Effects of role stress, job autonomy and social support. Administration in Social Work, 32(3), 5-25. https://doi.org/10.1080/03643100801922357

Kooij, D.T., Guest, D.E., Clinton, M., Knight, T., Jansen, P.G., \& Dikkers, J.S. (2013). How the impact of HR practices on employee well-being and performance changes with age. Human Resource Management Journal, 23(1), 18-35. https://doi.org/10.1111/1748-8583.12000

Kuo, H.T., Lin, K.C., \& Li, I.C. (2014). The mediating effects of job satisfaction on turnover intention for long-term care nurses in Taiwan. Journal of Nursing Management, 22(2), 225-233. https://doi.org/10.1111/jonm.12044

Kumar, R. (2016). The impact of personal variables on job satisfaction: A study of public sector bank employees in India. IUP Journal of Organizational Behavior, 15(3), 40.

Lam, T., Lo, A., \& Chan, J. (2002). New employees' turnover intentions and organizational commitment in the Hong Kong hotel industry. Journal of Hospitality \& Tourism Research, 26(3), 217-234. https://doi.org/10.1177/1096348002026003002

Lee, C.C., Huang, S.H., \& Zhao, C.Y. (2012). A study on factors affecting turnover intention of hotel empolyees. Asian Economic and Financial Review, 2(7), 866.

Lee, Y.J., \& Sabharwal, M. (2016). Education - Job match, salary, and job satisfaction across the public, non-profit, and for-profit sectors: Survey of recent college graduates. Public Management Review, 18(1), 40-64. https://doi.org/10.1080/1 4719037.2014.957342

Letchumanan, T., Apadore, K., \& Ramasamy, M. (2017). Factors influence turnover intention in commercial banks Malaysia: A theoretical model. Innovative Journal of Business and Management, 6(3), 13-21.

Liu, S., \& Onwuegbuzie, A. J. (2012). Chinese teachers' work stress and their turnover intention. International Journal of Educational Research, 53, 160-170. https://doi.org/10.1016/j.ijer.2012.03.006

Locke, E.A. (1969). What is job satisfaction? Organizational Behavior and Human Performance, 4(4), 309-336. https://doi.org/10.1016/0030-5073(69)90013-0

Luna-Arocas, R., \& Camps, J. (2007). A model of high performance work practices and turnover intentions. Personnel Review, 37(1), 26-46. https://doi. org/10.1108/00483480810839950

Mohammad, F.N., Chai, L.T., Aun, L.K., \& Migin, M.W. (2014). Emotional intelligence and turnover intention. International Journal of Academic Research, 6(4), 211220. 
Mosadeghrad, A.M. (2013). Occupational stress and turnover intention: Implications for nursing management. International Journal of Health Policy and Management, $1(2), 169$.

Mosadeghrad, A.M., \& Ferdosi, M. (2013). Leadership, job satisfaction and organizational commitment in healthcare sector: Proposing and testing a model. Materia Socio-medica, 25(2), 121.

Olusegun, S.O. (2013). Influence of job satisfaction on turnover intentions of library personnel in selected univerisities in South West Nigeria. Library Philosophy and Practice E-Journal, 914.

Qureshi, M.I., Iftikhar, M., Abbas, S.G., Hassan, U., Khan, K., \& Zaman, K. (2013). Relationship between job stress, workload, environment and employees turnover intentions: What we know, what should we know. World Applied Sciences Journal, 23(6), 764-770.

Raziq, A., \& Maulabakhsh, R. (2015). Impact of working environment on job satisfaction. Procedia Economics and Finance, 23, 717-725. https://doi.org/10.1016/S22125671(15)00524-9

Reilly, E., Dhingra, K., \& Boduszek, D. (2014). Teachers' self-efficacy beliefs, selfesteem, and job stress as determinants of job satisfaction. International Journal of Educational Management, 28(4), 365-378. https://doi.org/10.1108/IJEM-042013-0053

Salleh, R., Nair, M.S., \& Harun, H. (2012). Job satisfaction, organizational commitment, and turnover intention: A case study on employees of a retail company in Malaysia. World Academy of Science, Engineering and Technology, 72(1), 316-323.

Scanlan, J.N., \& Still, M. (2013). Job satisfaction, burnout and turnover intention in occupational therapists working in mental health. Australian Occupational Therapy Journal, 60(5), 310-318. https://doi.org/10.1111/1440-1630.12067

Tausif, M. (2012). Influence of non financial rewards on job satisfaction: A case study of educational sector of Pakistan. Asian Journal of Management Research, 2(2).

Willis Towers Watson. (2013). Higher turnover rate in Malaysian financial services industry, Towers Watson survey finds. TowersWatson.com, 2 October. Retrieved 5 December 2018 from https://www.towerswatson.com/en-MY/ Press/2013/10/Higher-turnover-rate-in-Malaysian-Financial-Services-industry.

Zhang, L.F., You, L.M., Liu, K., Zheng, J., Fang, J.B., Lu, M.M., \& Wu, X. (2014). The association of Chinese hospital work environment with nurse burnout, job satisfaction, and intention to leave. Nursing Outlook, 62(2), 128-137. https://doi.org/10.1016/j.outlook.2013.10.010

Zikmund, W.G., Babin, B.J., Carr, J.C., \& Griffin, M. (2009). Business research methods (8th ed.). New Castle: South-Western College Pub. 